\title{
Analyzing the attitudes of elite wrestlers related to the use of doping
}

\author{
Unal TURKCAPAR ${ }^{1}$, Mine KOC ${ }^{1}$, Mustafa KOC ${ }^{2}$ \\ ${ }^{1}$ School of Physical Education and Sports, Sütçü Imam University, Kahramanmaraş, Turkey. \\ 2 School of Physical Education and Sports, Adryaman University, Adryaman, Turkey. \\ Address correspondence to Mustafa Koc, mkoc@adiyaman.edu.tr
}

\begin{abstract}
The purpose of this study is to analyze the attitudes of elite Turkish wrestlers related to the use of doping. The study group of the research included freestyle and Greco-Roman (cadet, junior,and senior) 180 Turkish wrestlers in 2013 wrestling World Championship National Team training camps. In order to measure the attitudes of wrestlers, "The Attitude Scale Related to the Use of Doping" developed by Şapcı (2010) (3), and "Personal Information Form" developed by us were used. According to the research findings, in the sub-dimension of the attitude scale, "I disapprove trainers' encouraging the athletes upon the use of doping" had the lowest and "Use of doping causes unfair competition among the athletes" had the highest score. In comparisons according to the variables, whereas no significant difference was found in terms of style, diet, using nutritional support product, being national, caring for diet; significant differences were noticed in terms of being controlled of doping, category, level of education, and age of sports. Consequently, it can be said that attitude scores of elite wrestlers related to the use of doping are high and their attitude is positive.
\end{abstract}

Keywords: Doping, wrestling, attitude, sports.

\section{INTRODUCTION}

The wrestling that is defined as the subordination struggling of two wrestlers or people upon each other using their technical skills, strength, and intelligence in accordance with FILA rules without using any tools upon a wrestling mat at specific sizes (3) is an attempt people perform to maintain a healthy life or spend good time, and an activity people perform as a profession in a way that will take their full time and gain income.

Increasing of the material and moral returns of this sports branch appealing recently to large masses has made being successful inevitable. For that reason, considering winning as the main purpose in competitions encouraged athletes to use various substances, materials and ways to develop their performance (14).

A good sports performance depends upon physics, condition, diet, recreation, and life style. One or more than one of those not being at the required level can drive athletes to increase their performance preternaturally. Başkaya (2) defined doping as the athlete's using some substances in order to participate into a competition although not suitable medically or to increase their mental and/or physical performances through unnatural way (11).
The purpose of the athlete to use doping is to develop endurance, increase the muscle mass and strength, and delay the fatigue that will occur during exercise, accelerate recovery after training and competition, and prevent the dangerous effects of free $\mathrm{O}_{2}$ radicals and lactic acid-like substances forming during the exercise (8).

Use of doping in sports goes back to more ancient times then mentioned in the definition. It was reported in historical sources that the athletes ate mushroom to display more performance and gladiators used stimulants to fight better in sports competitions performed before Christ. In recent times, increase at material and moral benefits in sports and athletes' desire to be successful at all costs increased the rate of using doping (4).

It has been known that doping substances used frequently in almost all sports branches affect a performance positively in a short time, but on the other hand, when those are used for a long time at high doses, they have irremediable side effects such as psychological disorders leading even to psychosis, pilosity in females, skin rash, tumors, and liver disorders (10).

Especially in recent years, although the development in doping control methods and determination of the doping's serious side effects 
have encouraged athletes to find more natural methods for the performance improving, unconscious medication and increase at doping rates in several sports branches have attracted the attention in our country (4). Although doing is very dangerous and illegal, it comes into prominence as a saver beside the modern training methods $(1,16)$.

It is accepted that the disadvantages emerging as result of the doping use are known by the athletes. Despite this, insisting on using doping revealed a relationship increasing day by day between the irresistible attraction of records and winnings, gradual commercialization of sports, and professionalism (7).

The use of doping substances and methods is not much frequent in sports branches such as wrestling, boxing, taekwondo, and judo included among the fighting sports. Because the competitions in these sportive branches are performed according to bodyweight categorization, the athletes generally use diuretics in order to lose weight in a short time. Apart from this, use of amphetamine, heroin, and anabolic steroids has rarely been encountered, as well (6).

The intensity and severity of wrestling training and competition period, big material and moral benefits after the success directed some wrestlers to use medication unconsciously.

In recent times, it is really easy for the trainers and athlete at any branches or levels to reach these nutritional supplements and doping substances. If the sciences of medicine and sports do not fulfill what they should do and could not meet the needs and requests of athletes and trainers consciously, then the athletes will continue to take doping substances and supplements unconsciously. The purpose of our study is to analyze the attitudes and behaviors of elite wrestlers related to doping, and to provide contribution to the science.

\section{MATERIAL \& METHODS}

\section{Research Group}

The research population included elite Turkish wrestlers. Moreover, the sample included 180 elite Turkish wrestlers including 67 in cadet, 63 in junior, and 50 in senior categories present in Turkish national team camps (Freestyle, Greco-Roman) preparing to world championships in 2013.

\section{Data Collection Tools}

The research is quantitative and in descriptive screening model. In the research, "The Attitude Scale Related to the Use of Doping" developed by Şapcı (2010) (13), and "Personal Information Form" developed by the researcher asking for the opinions of specialists in which demographical information of elite Turkish wrestlers were asked were used as the data collection tools. The scale questions included two parts. In the first part, the personal information, and in the second part, the expressions related to the attitudes of wrestlers related to doping $(8,10)$ were included. The scale was performed to the wrestlers through the trainers or interviewing directly as face to face.

\section{Data Analysis}

In the research, SPSS 15 package program was used; and frequency, standard deviation, and percentage values were used in the analysis of personal information of the participants. For comparing the scores taken from the attitude scale, t-test, ANOVA, and Tukey tests were used. The level of statistical significance was taken as $p=0.05$ in analysis.

\section{RESULTS}

In Table 1, the arithmetic average and standard deviation values related to scores taken from the expressions creating the Attitude Scale were presented. When the table was analyzed, the score averages were noticed to vary between (mean $=3.52)$ and (mean=4.37). The highest expression score average was (mean=4.37) related to the expression of "Doping use causes unfair competition among the athletes;" and the lowest score average was (mean=3.52) related to the expression of "I disapprove trainers' encouraging the athletes upon doping use." The score averages of the other expressions were as; "I disapprove athletes' use of doping" was (mean=3.80), "Use of doping in sports should be fully released" was (mean=4.28), "I can use doping without hesitation if it provides me to be successful" was (mean=4.22), "I consider that doping use seriously threatens the health of athletes" was (mean=4.25), "Doping controls should be increased in frequency" was (mean=4.11), "Use of doping is not a behavior in accordance with the sports ethics" was (mean=4.17), "I can use doping for the success of my country in a big sportive organization" was $($ mean $=4.00)$, and "Doping is a very serious problem for the sports world" was (mean=4.35). 
Table 1. Attitude scale scores average and standard deviation values.

\begin{tabular}{|c|c|c|c|}
\hline Scale Expressions & $\mathrm{N}$ & Mean & SD \\
\hline I disapprove athletes' use of doping. & 180 & 3.80 & 1.57 \\
\hline Use of doping in sports should be fully released. & 180 & 4.28 & 1.12 \\
\hline I disapprove trainers' encouraging the athletes upon doping use. & 180 & 3.52 & 1.61 \\
\hline I can use doping without hesitation if it provides me to be successful. & 180 & 4.22 & 1.19 \\
\hline I consider that doping use seriously threatens the health of athletes. & 180 & 4.25 & 1.14 \\
\hline Doping controls should be increased in frequency. & 180 & 4.11 & 1.20 \\
\hline Use of doping is not a behavior in accordance with the sports ethics. & 180 & 4.17 & 1.21 \\
\hline I can use doping for the success of my country in a big sportive organization. & 180 & 4.00 & 1.27 \\
\hline "Doping" is a very serious problem for the sports world. & 180 & 4.35 & 0.95 \\
\hline Doping use causes unfair competition among the athletes. & 180 & 4.37 & 1.01 \\
\hline General & 180 & 4.11 & 0.87 \\
\hline
\end{tabular}

Table 2. T-test results of the scores taken from the attitude scale related to the use of doping according to score averages of wrestlers' style, nutritional support product, assignment in national team, doping control, caring for diet.

\begin{tabular}{|c|c|c|c|c|c|c|c|}
\hline & & Variable & $\mathrm{N}$ & Mean & SD & $\mathrm{t}$ & $\mathrm{P}$ \\
\hline \multirow{10}{*}{ 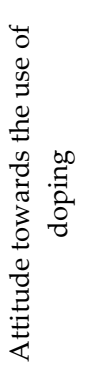 } & \multirow[t]{2}{*}{ Wrestling Style } & Freestyle & 95 & 4.12 & 0.89 & 0.214 & 0.830 \\
\hline & & Greco-Roman & 85 & 4.09 & 0.87 & & \\
\hline & \multirow{2}{*}{$\begin{array}{l}\text { Using nutritional support } \\
\text { product }\end{array}$} & Using & 47 & 4.14 & 0.68 & 0.335 & 0.738 \\
\hline & & Not using & 133 & 4.10 & 0.94 & & \\
\hline & \multirow{2}{*}{$\begin{array}{l}\text { Assignment in national } \\
\text { team }\end{array}$} & National & 110 & 4.19 & 0.89 & 1.497 & 0.136 \\
\hline & & Not national & 70 & 3.99 & 0.84 & & \\
\hline & \multirow[t]{2}{*}{ Doping control } & Controlled & 62 & 4.30 & 0.77 & 2.157 & $0.032^{*}$ \\
\hline & & Uncontrolled & 118 & 4.01 & 0.91 & & \\
\hline & \multirow[t]{2}{*}{ Caring for diet } & Caring & 159 & 4.11 & 0.89 & -0.010 & 0.992 \\
\hline & & Not caring & 21 & 4.11 & 0.81 & & \\
\hline
\end{tabular}

According to the performed $t$-test results, there was no significant difference between the attitudes score averages related to the use of doping in terms of the styles of elite wrestlers. Attitude score averages of freestyle wrestlers was (mean $=4.12$ ), and attitude score averages of Greco-Roman wrestlers was (mean=4.09).

There was no significant difference between the attitudes score averages of wrestlers related to the use of doping in terms of using nutritional support products. The attitude score averages of the wrestlers using nutritional support product related to the use of doping was (mean=4.14), and the score averages of the wrestlers not using support products was (mean $=4.10)$.

There was no significant difference between the attitudes score averages of wrestlers related to the use of doping in terms of being assigned in the national team. However, attitude score averages of the wrestlers assigned in National teams related to the use of doping was (mean=4.19) higher than the attitude score averages (mean=3.99) of the wrestlers not assigned in National teams.

When the wrestlers' controlled or uncontrolled from the doping control was analyzed, there was a statistically significant difference between the attitude score averages of wrestlers related to the use of doping $(t=2.157, p<0.05)$. Attitude score averages of the wrestlers controlled from the doping control was (mean=4.30), and the attitude score averages of the wrestlers uncontrolled in doping control was more positive as (mean=4.01).

According to the wrestlers' caring for their diet, there was no significant difference between their attitudes score average related to the use of doping. Whereas the attitude score averages of the wrestlers caring for their diet was (mean=4.11), the attitude score average of the wrestlers not caring for their diet was (mean=4.11).

The difference between the attitudes of elite wrestlers in different categories related to the use of doping was statistically significant $\left(\mathrm{F}_{(2-177)}=3.458\right.$, $\mathrm{p}<0.05$, Table 3 ). When we analyzed the average 
values, we noticed that the score average of cadet wrestlers was (mean=3.97), the score average of junior wrestlers was $(m e a n=4.04)$, and the score average of senior wrestlers was (mean=4.38). As the age of the athlete got older, their attitudes towards the use of doping increased positively.

According to Tukey test results, in attitudes of wrestlers related to the use of doping, there was a statistically significant difference between the score averages of cadet wrestlers and score averages of the elite wrestlers in seniors category $(\mathrm{p}<0.05$; Table 4$)$. Attitude score average of the wrestlers in seniors' category was higher than the attitude score averages of the cadet wrestlers.

According to the educational status of wrestlers, the difference between the attitude score averages related to the use of doping was statistically significant $\left(F_{(2-177)}=6.395 ; p<0.05 ;\right.$ Table 5$)$.
When analyzing the average values, score average of the secondary education graduate wrestlers was (mean=3.23), the score average of the high school graduates was (mean $=4.05)$, and the score average of the university graduates was (mean=4.42). As the educational level of the wrestlers increased, a positive increase was determined in attitudes of wrestlers related to the use of doping.

According to Tukey test results, there was a significant difference between the attitude score averages of university graduate wrestlers and attitude score averages of high school graduate wrestlers in their attitudes related to the use of doping $(\mathrm{p}<0.05$; table 6$)$. Attitude score average of the university graduate wrestlers was higher than the attitude score averages of the secondary and high school graduate wrestlers.

Table 3. ANOVA results of the scores taken from the attitude scale related to the use of doping according to the categories of wrestlers.

\begin{tabular}{lllllll}
\hline & Category & N & Mean & SD & F & P \\
\hline \multirow{3}{*}{ Attitude Towards the Use of } & Cadet & 67 & 3.97 & 0.95 & & \\
Doping & Junior & 63 & 4.04 & 0.93 & 3.458 & $0.034^{*}$ \\
& Senior & 50 & 4.38 & 0.63 & & \\
& & & & & & \\
\hline${ }^{*} \mathrm{p}<0.05$ & & & & & &
\end{tabular}

Table 4. The analysis results revealing the comparison of scores taken from the attitude scale related to the use of doping with Tukey test according to the categories of wrestlers.

\begin{tabular}{lllcc}
\hline & Category & & Difference of Averages & $\mathrm{P}$ \\
\hline & & & & \\
& \multirow{2}{*}{ Cadet } & Junior & -0.07420 & 0.876 \\
& & Senior & -0.40734 & $0.033^{*}$ \\
& \multirow{2}{*}{ Junior } & Senior & -0.33314 & 0.107 \\
& & & & \\
\hline${ }^{*} \mathrm{p}<0.05$ & &
\end{tabular}

Table 5. ANOVA results of the scores taken from the attitude scale related to the use of doping according to the educational status of wrestlers.

\begin{tabular}{llccccc}
\hline & Education & N & Mean & SD & F & P \\
\hline \multirow{3}{*}{ Attitude Towards the Use of } & Secondary & 6 & 3.23 & 1.19 & 6.395 & $0.002^{*}$ \\
Doping & High School & 131 & 4.05 & 0.91 & & \\
& University & 43 & 4.42 & 0.55 & & \\
& & & & & & \\
\hline${ }^{*} \mathrm{p}<0.05$ & & & & & &
\end{tabular}

Table 6. The analysis results revealing the comparison of scores taken from the attitude scale related to the use of doping with Tukey test according to the educational status of wrestlers.

\begin{tabular}{|c|c|c|c|c|}
\hline & & bles & Difference of Averages & $\mathrm{P}$ \\
\hline \multirow{3}{*}{$\begin{array}{l}\text { Attitude Towards the Use of } \\
\text { Doping }\end{array}$} & Secondary & High School & -0.81247 & 0.060 \\
\hline & & University & -1.18527 & $0.005^{*}$ \\
\hline & High School & University & -0.37280 & $0.036^{*}$ \\
\hline
\end{tabular}


Table 7. ANOVA results of the scores taken from the attitude scale related to the use of doping according to the sports age of wrestlers.

\begin{tabular}{lllllll}
\hline & Age of Sports & N & Mean & SD & F & P \\
\hline \multirow{3}{*}{ Attitude Towards the Use of } & & & & & & \\
Doping & 1-3 Years & 10 & 3.81 & 1.01 & 4.072 & $0.008^{*}$ \\
& 4-6 Years & 82 & 3.91 & 0.95 & & \\
& 7-9 Years & 34 & 4.21 & 0.83 & & \\
& 9 Years and Over & 54 & 4.40 & 0.65 & & \\
& & & & & & \\
\hline
\end{tabular}

${ }^{*} \mathrm{p}<0.05$

Table 8 . The analysis results revealing the comparison of scores taken from the attitude scale related to the use of doping with Tukey test according to the sports age of wrestlers.

\begin{tabular}{|c|c|c|c|c|}
\hline & & Variables & Difference of Averages & $\mathrm{P}$ \\
\hline \multirow{6}{*}{$\begin{array}{l}\text { Attitude Towards the Use of } \\
\text { Doping }\end{array}$} & 1-3 Years & 4-6 Years & -0.10 & 0.984 \\
\hline & & 7-9 Years & -0.40 & 0.571 \\
\hline & & 9 Years and Over & -0.59 & 0.192 \\
\hline & 4-6 Years & 7-9 Years & -0.29 & 0.334 \\
\hline & & 9 Years and Over & -0.49 & $0.008^{*}$ \\
\hline & 7-9 Years & 9 Years and Over & -0.19 & 0.733 \\
\hline
\end{tabular}

${ }^{*} \mathrm{p}<0.05$

There was a significant difference between the attitude score averages of elite wrestlers related to the use of doping according to their sports ages $\left(\mathrm{F}_{3-3}\right.$ 176) $=4.072 ; \mathrm{p}<0.05$; Table 7). Attitude score averages of the athlete with 1-3 years old sports age was (mean=3.81), attitude score averages of the athletes with 4-6 years old sports age was (mean=3.91), and attitude score averages of the athletes with 7-9 years old sports age was (mean=4.21), and the attitude score averages of the athletes with 9 years and over sports age was (mean=4.40). As the sports age of the wrestlers increased, their attitudes towards the use of doping increased positively.

According to Tukey test, a statistically significant difference was found between the wrestlers with 4-6 years sports age and the ones with 9 year and over sports age.

\section{DISCUSSION}

As result of the research in which attitudes towards the use of doping was analyzed in elite Turkish wrestlers, it was concluded that there were significant differences according to different age groups (Table 3). Whereas the attitude score average (mean=3.97) towards doping use in cadet category was at a medium level, it was also concluded that attitude score averages increased to a high level as the age category increased (seniors: mean $=4.38$ ). In his study in (13) Şapçı determined that attitude scores of athletes related to doping use did not change according to the variable of age. However, Şapçı (13) limited his study only with the university students. The results of our study were inconsistent with the results of Şapcı (13).

In accordance with the data obtained with this study, the wrestlers answered to the scale mentioned that they intensely used doping and ergogenic support substances to improve performance.

According to another finding of the research, there was no significant difference between the attitude score averages of elite wrestlers towards doping use in terms of their styles. Attitude score averages of freestyle wrestlers was (mean $=4.12)$, and attitude score averages of Greco-Roman wrestlers was (mean=4.09). No significant difference at attitude score averages according to wrestling styles considered us that the depended variable did not change in wrestling styles.

According to the research result, the difference between the attitude score averages of wrestlers towards doping use according to their level of education was statistically significant $\left(\mathrm{F}_{(2-177)}=6.395\right.$, $\mathrm{p}<0.05)$. As the educational level of the wrestlers increased, a positive increase was determined in their attitudes towards doping use. In their study in (5) carried out upon students studying at Vocational High Schools of Physical Education and Sports, Çetinkayaet al. concluded that there were significant differences according to the educational grades of students. The results of our study showed parallelism with the results of the study carried out by Çetinkaya et al. (5). 
According to the athletes' being national, no significant difference was determined between their attitude score averages. Because there was also no difference between the attitude score averages according to being national in the study of Şapçı (13), it showed parallelism with our study. For that reason, it was revealed that being interested in sports at a national level did not change the attitudes towards doping use. This proved that the athlete had knowledge at a similar level about the behaviors related to doping use or displaying similar attitudes. However, this did not provide sufficient information about the doping necessary for aathlete.

Attitudes of elite wrestlers towards doping use showed significant difference according to the sports age. It was noticed that the attitudes of the wrestlers who had "9 years and over" sports age $($ mean $=4.40)$ were more positive rather than the attitudes of the wrestlers with " $4-6$ years" sports age (mean=3.91). Being a wannabe or the desire to reach to a conclusion early come to forefront especially in athletes with young sports age, and this can direct them to use doping substances without any hesitation (15). According to the results of a research carried out to measure the doping knowledge levels of elite athletes, a significant difference was determined according to sports age between the score averages (mean=2.00) of participants with " $0-4$ years" sports age and the ones with 16 years and over" sports age (mean=1.25). Consequently, it was noticed that the athletes with higher sports age were more informed on this issue rather than the ones with less sports age (9). For that reason, it showed parallelism with the results of our study.

It was also determined as result of our research that majority of elite wrestlers did not consider doping use as ethical in accordance with difference purposes or to improve the performance. It was also concluded in the study of Öztürk in (12) that athletes did not consider taking ergogenic support as an ethical and honest behavior pattern. The results of our research and the results of the research carried out by Öztürk (12) showed parallelism with each other.

In the light of whole these results, the suggestions below can be concluded at the end of the attitude scale related to doping use in Elite Turkish Wrestlers:

- The issues of finance should be dealt with about the struggling against doping, and trainers who will train around the country on doping should be provided. These trainers should conduct seminars to coaches, clubs, club managers and athletes on doping and ergogenic support.

- The meaning of sports and its purpose should constantly be expressed, and the athletes should be provided to acquire the sports culture.

- Psychological training should be provided to athletes to encourage on not using doping.

-Whether the substances and methods used by the athletes are included into the Doping List published by WADA should be controlled, and the athletes should be informed about this.

\section{REFERENCES}

1. Acarbay Ş. Spor Sporcu ve Doping. Milli Eğitim Basımevi. Ankara: 1986.

2. Başkaya C. Doping Kazanmak Uğruna Ölmek. Özgür Üniversite Forumu, 2004; (25): 610.

3. Calvert TW, Banister MV, Savega TM, Bach A. System model of the effects of training on physical performance. IEE trans on systems. Man and Cybernetics, 1976; 6(2): 94-99.

4. Çetin E, Ertaş Dölek B, Orhan Ö. Gazi Üniversitesi Beden Eğitimi ve Spor Yüksekokulu öğrencilerinin ergojenik yardimcilar. doping ve sağlik hakkindaki bilgi ve alişkanliklarinin belirlenmesi. Spormetre Beden Eğitimi ve Spor Bilimleri Dergisi, 2008; 6(3): 129-132.

5. Çetinkaya G, Ağyar E, Dilbaz KÖ. Beden Eğitimi ve Spor Yüksekokullarındaki öğrencilerin doping konusundaki bilgi düzeyleri ve tutumlarinin incelenmesi (Akdeniz Üniversitesi Örneği). 4. Akdeniz Spor Bilimleri Kongresi. Antalya: 9-11 Kasım, 2007.

6. Erkiner K. Sporda Doping Gerçeği. (20 Mart 2010). www.sporhukuku.org/download/2_sporda_doping_gercegi. doc 2008.

7. Eröz MF. Milli Düzeyde Atletizm, Güreş, Judo ve Halter Yapan Sporcuların Doping ve Ergojenik Yardım Hakkındaki Görüşlerinin ve Bilgi Düzeylerinin Belirlenmesi. Dumlupınar Üniversitesi, Yüksek Lisans Tezi, Kütahya, 2007.

8. Ersoy G. Sağlıklı Yaşam Spor ve Beslenme. Ankara: Damla Matbaasi. 1998.

9. Gençtürk G, Çolakoğlu T, Demirel M. A research for determine the intelligence level of national sportsman for doping (wrestling sample). Nigde University Journal of Physical Education and Sport Sciences, 2009; 3(3): 213-221.

10. Güler D, Gökdemir K, Günay M. Türkiye'de üniversitelerarasi spor oyunlarina katilan futbolcularin ergojenik yardimcilar hakkindaki bilgileri ve kullanma düzeyleri. Gazi Üniversitesi Beden Eğitimi ve Spor Bilimleri Dergisi, 2004; 9(3): 37-78.

11. Güner R. Doping: Tff Dopingle Mücadele Kurulu. Ankara: Afşaroğlu Matbaası, 2000.

12. Öztürk EG. Türkiye'de Doping, Sporcuların Doping Bilgi Düzeylerinin Ölçülmesi (Hentbol Örneği). Yüksek Lisans 
Tezi, Eğitim Bilimleri Enstitüsü, GaziÜniversitesi, Ankara, 2009.

13. Şapçı HA. Üniversiteler Arası Spor Müsabakalarına Katılan Öğrencilerin Doping Kullanımına Yönelik Tutumlarının İncelenmesi. Yüksek Lisans Tezi, Gazi Üniversitesi, Ankara, 2010.

14. Şenel Ö, Güler D, Kaya İ, Ersoy A, Kürkçü R. The level of knowledge on how to use ergogenic aids among elite class Turkish athletes in different individual branches. Spormetre Journal of Physical Education and Sport Sciences, 2004; 2(2): 41-47.

15. Yıldız A. Cumhuriyet Üniversitesi Beden Eğitimi ve Spor Yüksekokulu ve Sivas İli Amatör Liglerinde Değişik Branşlardaki Sporcuların Doping Kullanım Oranlarının Araştırılması. Yüksek Lisans Tezi, Cumhuriyet Üniversitesi, Sivas, 2006.

16. Yoncalık O, Gündoğdu C. Doping as a morality problem in the elite sport. Research Eastern Anatolia Region, 2007; 6(1): 128-134. 